JURNAL PENGABDIAN KEPADA MASYARAKAT

MAKARDHI

MANGANJALI KARYA WERDHI
Jurnal Pengabdian Kepada Masyarakat Makardhi P-ISSN 2302-8343| E-ISSN 2581-2122

Vol. 1 No. 1 -Juni 2021

DOI: $10.52352 /$ makardhi.v1i1.598

Publisher: P3M Politeknik Pariwisata Bali

Available online: https://ejournal.ppb.ac.id/index.php/makardhi

\title{
Floral Art Design: Potensi Kewirausahaan di Desa Wisata Gunung Salak, Tabanan, Bali
}

\author{
Ida Ayu Sri Puspa Adi' ${ }^{1}$ I Gusti Ayu Putu Wita Indrayani2, Ni Ketut Iswarini ${ }^{3}$, \\ I Putu Gede Eka Darmaputra ${ }^{4}$ \\ 1,2,3,4 Program Studi Manajemen Divisi Kamar, Jurusan Hospitaliti, Politeknik Pariwisata Bali \\ Jalan Dharmawangsa, Kampial, Nusa Dua, Kabupaten Badung \\ ${ }^{1}$ sripuspaadi1101@gmail.com
}

\begin{abstract}
\begin{tabular}{c|c|c}
\hline Received: Mei, 2021 & Accepted: Mei, 2021 & Published: June, 2021 \\
\hline
\end{tabular}
Abstract

This article aims to discuss the implementation of Community Service activities in Gunung Salak Tourism Village, Tabanan, Bali with the topic: floral art design. The activity was carried out for one full day on April 7, 2021 at Banjar Kemetug with participants mostly from young people. This training activity was carried out using demonstration, question and answer, and working in groups. The results showed that this activity increased the insight and knowledge of the participants in Gunung Salak Tourism Village in utilizing the natural potential in their village and empowering local genius skills possessed in processing coconut leaves. Insights, basic knowledge, and simple flower arrangement skills taught by the facilitators are expected to be developed into entrepreneurial ventures for the village community because they have good business prospects at this time.
\end{abstract}

Keywords: floral art design, entrepreneurship, village tourism, community development

\begin{abstract}
Abstrak
Penulisan ini bertujuan untuk membahas pelaksanaan kegiatan Pengabdian kepada Masyarakat di Desa Wisata Gunung Salak, Tabanan, Bali dengan topik: floral art design. Kegiatan dilaksanakan selama satu hari penuh pada tanggal 7 April 2021 bertempat di Banjar Kemetug dengan peserta sebagian besar dari kalangan pemuda dan pemudi. Kegiatan pelatihan ini dilaksanakan dengan metode demonstrasi, tanya jawab, dan bekerja dalam kelompok. Hasil dari kegiatan ini meningkatkan wawasan dan pengetahuan masyarakat di Desa Wisata Gunung Salak dalam memanfaatkan potensi alam di desanya dan memberdayakan keterampilan local genius yang dimiliki dalam mengolah janur. Wawasan, pengetahuan dasar, dan keterampilan merangkai bunga sederhana yang diajarkan oleh para fasilitator diharapkan dapat ditingkatkan menjadi usaha kewirausahaan bagi masyarakat desa karena memiliki prospek bisnis yang baik saat ini.
\end{abstract}

Kata kunci: seni merangkai bunga, kewirausahaan, desa wisata, pembangunan masyarakat 


\section{PENDAHULUAN}

Desa Wisata Gunung Salak adalah desa wisata yang terletak di Desa Gunung Salak kecamatan Selemadeg Timur, Kabupaten Tabanan dengan luas wilayah seluas 1014 hektar yang terdiri dari lima Banjar/Dusun Dinas yaitu Banjar Kemetug, Banjar Kemetug Kanciana, Banjar Apit Yeh, Banjar Bangkiang Sidem, dan Banjar Gunung Salak. Wilayah Desa Gunung Salak berbatasan dengan Desa Dalang di bagian Utara, sebelah timur dengan Tukad Yeh Lambuk, dan Tukad Bunuhan disebelah Barat serta Desa Megati disebelah Selatan. Adapun jarak tempuh desa Gunung Salak dari Airport Internasional I Gusti Ngurah Rai sepanjang $\pm 39 \mathrm{~km}$. Desa Gunung salak juga dapat dikunjungi melalu jalur darat yaitu $\pm 71 \mathrm{~km}$ dari Gilimanuk.

Masyarakat di Desa sebagian besar memiliki mata pencaharian sebagai petani. Lahan pertanian di desa Wisata Desa Gunung Salak sangat luas, sehingga dalam mengembangkan berbagai aktivitas wisata selalu berkenaan dengan alam dan kehidupan masyarakat petani. Secara geografis, daerah ini memiliki pemandangan alam yang indah dengan hamparan sawah (rice terrace) yang luas, sehingga dikembangkan area trekking dan aktivitas spiritual. Di Desa Gunung salak terdapat 12 mata air yang dipercaya memiliki fungsi untuk melukat (ruwatan), penyembuhan, meditasi, dan desa ini juga memiliki 3 air terjun yang indah yakni air terjun Tibu Sampi, air terjun Batu Tumpuk, dan air terjun Batu Sangian.

Sejak bulan Maret 2017, Desa Gunung Salak ditetapkan sebagai salah satu desa wisata secara resmi, karena potensi alam yang dimiliki. Namun desa wisata ini belum banyak dikenal oleh orang karena minimnya promosi yang dilakukan baik di media cetak maupun media elektronik ini adalah salah satu penyebabnya. sehingga potensi alam di Desa Gunung Salak belum banyak diketahui oleh masyarakat luas (Radar Bali online, 2018) dalam Suprastayasa, Adi, dan Iswarini (2020).

Menurut Dewi dan Sunarta bahwa pertumbuhan desa wisata dengan berbagai atraksi wisata baru di berbagai kabupaten dan kota sejalan dengan perkembangan pariwisata Bali. Berbagai daya Tarik wisata yang dikembangkan dalam desa wisata bervariasi dari daya Tarik wisata yang menyuguhkan pemandangan alam, atraksi wisata buatan sampai daya tarik wisata yang menampilkan berbagai adat istiadat, budaya dan kesenian local. Potensi yang dimiliki oleh desa Gunung Salak sebagai salah satu desa wisata namun terdapat berbagai kendala yang dihadapi, sebagaimana dikemukakan oleh Dewi dan Sunarta (2018) yaitu permodalan, sumber daya manusia, dan promosi. Lebih jauh disebutkan bahwa masyarakat Desa Gunung Salak masih sebagian besar belum memahami pariwisata. Kurangnya sumber daya manusia di bidang pariwisata, mengakibatkan perkembangan kegiatan kepariwisataan yang lambat dalam Suprastayasa, Adi, dan Iswarini (2020).

Adiyoso (2009) menegaskan bahwa partisipasi masyarakat merupakan komponen terpenting dalam upaya pertumbuhan kemandirian dan proses pemberdayaan. Pengabaian partisipasi masyarakat lokal dalam pengembangan desa wisata menjadi awal dari kegagalan tujuan pengembangan desa wisata dalam Dewi, Fandeli \& Baiquni (2013). 


\section{METODE PELAKSANAAN KEGIATAN}

Kegiatan pelatihan floral art design ini dilaksanakan di Desa Gunung Salak, Kecamatan Selemadeg Timur, Kabupaten Tabanan. Kegiatan dilaksanakan selama satu hari penuh pada tanggal 7 April 2021 dengan jumlah peserta sebanyak 30 orang. Peserta merupakan masyarakat lokal dengan latar belakang yang bervariasi, baik dari segi pendidikan, pendapatan, dan profesi. Dalam kegiatan ini, data dikumpulkan melalui teknik obvervasi partisipasi (participatory observation), dimana pendekatan partisipatif menawarkan kepada subjek penelitian untuk menentukan apa yang sedang dipelajari, dan mengajarkan anggota masyarakat dasar-dasar metodologi penelitian sehingga mereka dapat mengambil peran kolaboratif (Clark et al., 2009). Partisipasi memiliki potensi untuk melibatkan orang dalam semua aspek proses kegiatan. Untuk mencapai tujuan dalam kegiatan ini, metode partisipatif dalam bentuk pelatihan merupakan cara yang lebih relevan dan non-hierarkis yang juga dapat bersifat emansipatoris (Kesby, 2000; Pain, 2004; Clark et al., 2009). Untuk mengkonfirmasi dan memperkuat hasil yang didapatkan dari observasi partisipasi, maka dilakukan wawancara semi terstruktur dengan para pengurus Desa Gunung Salak.

Proses pelatihan floral art design ini dibagi menjadi tiga aktivitas utama. Aktivitas pertama adalah ceramah yang bertujuan untuk memberikan pengetahuan dasar mengenai teknik seni floral yang menekankan pada unsur dan prinsip dasar merangkai bunga. Pengetahuan dasar ini sangat penting untuk diberikan pada awal kegiatan karena karakteristik peserta yang cukup bervariasi. Aktivitas berikutnya adalah demonstrasi dan pelatihan. Dua orang fasilitator yang telah tersertifikasi kompetensi di bidang merangkai bunga mendemonstrasikan beberapa jenis rangkaian, baik rangkaian bunga modern/kontemporer, tradisional, modifikasi, dan hand bouquette. Setelah peserta memperhatikan demonstrasi dari para fasilitator, peserta dibagi menjadi beberapa kelompok kerja dan diminta untuk membuat rangkaian bunga mulai dari persiapan bahan, pemilihan kombinasi bahan dan warna, hingga pembersihan. Kerja kelompok tersebut tetap dipandu dan dibimbing oleh fasilitator. Aktivitas terakhir adalah evaluasi kegiatan. Evaluasi pada hasil akhir rangkaian disampaikan agar para peserta mendapatkan feedback atas hasil kerjanya dan mengetahui kekurangan serta aspek-aspek yang perlu diperbaiki.

\section{HASIL DAN PEMBAHASAN \\ 3.1 Pelaksanaan Kegiatan}

Kegiatan pelatihan floral art design ini merupakan kelanjutan dari program serupa yang telah dilaksanakan pada tahun 2020. Kegiatan pelatihan tahun 2020 belum dapat dijalankan secara optimal karena merupakan periode awal pandemi COVID-19 yang membuat banyak perubahan dan keterbatasan dalam melaksanakan program. Beberapa aspek yang belum dijalankan secara optimal tahun sebelumnya menjadi catatan penting dalam melakukan berbagai penyesuaian, terutama dalam kaitannya dengan program Kementerian Pariwisata untuk menstimulus usahausaha kewirausahaan dan penerapan protokol kesehatan dalam melaksanakan kegiatan. Untuk dapat mensinkronisasi program yang dapat ditawarkan dengan kebutuhan riil di Desa Wisata Gunung Salak, maka diinisiasi kegiatan penjajagan oleh tim pelaksana pada awal tahun 2021. Dalam penjajagan ini dapat teridentifikasi 
kebutuhan pelatihan sesuai dengan analisis situasi yang diperoleh dari pengurus desa. Dari hasil tersebut, tim pelaksana melakukan kordinasi internal dengan seluruh tim untuk menyusun program kerja, materi pelatihan, fasilitator, jadwal kegiatan, bahan yang diperlukan, serta anggaran yang harus dialokasikan untuk memaksimalkan kegiatan ini. Kordinasi ekternal dengan pengurus desa juga dilakukan secara intensif untuk dapat mengantisipasi segala kemungkinan yang berpotensi terjadi.

\subsection{Analisis Hasil Kegiatan dan Kendala yang Dihadapi}

Desa Wisata Gunung Salak memiliki banyak potensi alam yang dapat dimanfaatkan untuk pengembangan desa. Suasana pedesaan yang alami serta kontur wilayah dataran tinggi membuat berbagai jenis tanaman dapat tumbuh dengan subur di daerah ini. Sumber daya alam ini sangat berpotensi untuk dikembangkan menjadi usaha kewirausahaan. Maka dari itu, sebagian bahan-bahan yang dipergunakan dalam pelatihan ini merupakan hasil dari Desa Wisata Gunung Salak, seperti janur dan bunga serta daun lokal. Dalam pelatihan ini juga ditekankan bahwa pemanfaatan bahan-bahan yang mudah ditemukan di sekitar tempat tinggal peserta dapat dioptimalisasi sedemian rupa dengan cara dikemas menjadi produk baru yang inovatif dan memiliki nilai komersial.

Dalam pelatihan ini masyarakat yang dilibatkan sebagai peserta berasal dari beberapa wilayah (banjar). Peserta sebagian besar merupakan penduduk asli Bali yang sudah familiar dengan kreasi janur. Pemanfaaatan janur bagi masyarakat Bali sebagai salah satu instrumen kreasi seni tradisional bukanlah sesuatu yang asing. Ketika ditanyakan seberapa familiar dengan kreasi janur, salah satu peserta yang merupakan Ibu Rumah Tangga mengatakan:

"Saya hampir setiap hari bersentuhan dengan janur. Karena selalu membuat canang untuk keperluan persembahyangan sehari-hari. Saya juga sering ngayah di banjar, buat banten dan sarana upakara. Jadi kalau bisa dibilang ya cukup sering saya metetuesan (menoreh janur)."

Peserta lain yang berjenis kelamin laki-laki yang kebetulan bekerja di sektor pariwisata juga mengatakan hal yang kurang lebih sama:

“ Orang Bali kan sudah biasa menorah janur, karena banyak kegiatan adat yang mengharuskan berurusan dengan janur. Laki-laki juga sama. Buat penjor kan juga pakai janur. Jadi bisa dibilang sudah lumrah untuk perempuan dan laki-laki. Cuman kalau untuk mengkombinasi dengan bunga seperti ini ya belum pernah sepertinya."

Secara umum kegiatan berjalan dengan lancar karena pengetahuan serta kemampuan dasar menoreh janur sudah dimiliki sebagian peserta. Materi pelatihan ini menitikberatkan pada kombinasi bahan lokal (janur) yang dibentuk menjadi beberapa kreasi dan dipadupadankan dengan bunga serta daun-daun yang bisa ditemukan di sekitar tempat tinggal peserta. Bahan-bahan yang terbatas pun dapat 
dikreasikan dan dikemas menjadi produk seni floral yang bisa diperjualbelikan. Proses pembuatan hingga hasil rangkaian dapat dilihat pada beberapa foto berikut:

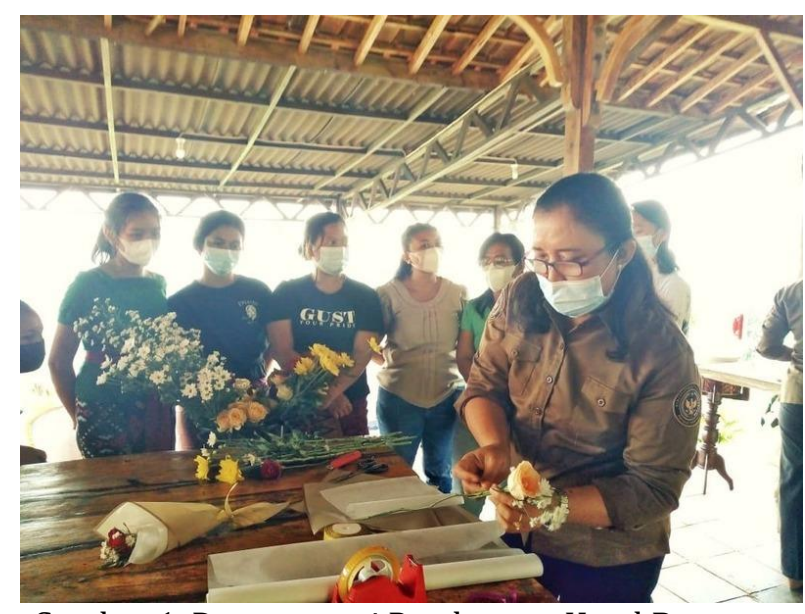

Gambar 1. Demonstrasi Pembuatan Hand Bouquett

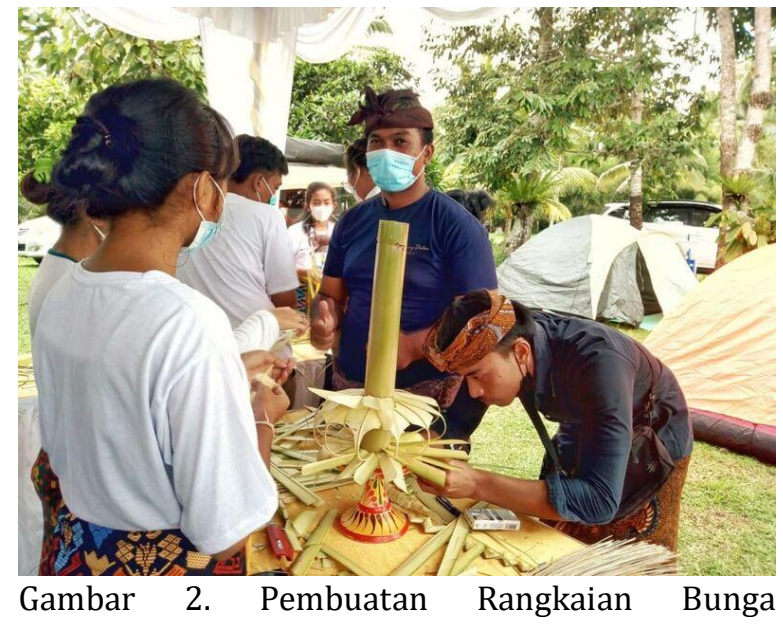

Tradisional

Dari beberapa dokumentasi tersebut, dapat dilihat bahwa sebagian besar rangkaian sudah memenuhi kriteria minimum dalam prinsip merangkai bunga. Adapun prinsip dasar merangkai yang digunakan sebagai acuan dalam memberikan evaluasi pada hasil akhir rangkaian adalah:

1) Kesatuan (unity). Prinsip ini tercermin dari kesatuan tema yang diwujudkan melalui rangkaian, misalnya rangkaian modern/kontemporer, rangkaian tradisional, dan hand bouquette.

2) Komposisi (composition). Prinsip ini tercermin dari tata letak, pengaturan, dan penataan material serta elemen floral dalam suatu rangkaian.

3) Proporsi (proportion). Prinsip ini dapat dilihat dari perbandingan atau kombinasi dan perpaduan bahan, warna, serta tekstur dalam rangkaian bunga. Rangkaian bunga yang baik adalah rangkaian bunga yang dibuat secara proposional dari segi perbandingan ukuran, baik perbandingan antara ukuran rangkaian dengan ukuran wadah, atau perbandingan ukuran rangkaian bunga keseluruhan dengan lokasi (venue).

4) Keseimbangan (balance). Prinsip ini terlihat dari rangkaian yang stabil dan tidak mudah goyah. Hasil rangkaian peserta sudah cukup baik, namun yang perlu diperhatikan adalah karakteristik bahan media tancap (floral foam) yang tidak fleksibel dan rapuh. Beberapa peserta kurang hati-hati dalam menancapkan batang bunga/daun/janur ke media tancap, sehingga membuat floral foam menjadi rusak dan tidak bisa dipergunakan kembali. Padahal media tancap sangat menentukan kestabilan dan keseimbangan rangkaian.

5) Irama (rhythm). Prinsip ini tercermin melalui repetisi, transisi, dan kedalaman penancapan. Hasil rangkaian hand bouquette peserta masih terkesan monoton dan belum mencerminkan transisi yang terstruktur dalam pemasangan atau penancapan material floral. Namun demikian, 
kekurangan ini dapat tertutupi dengan pemasangan wrapping paper dengan berbagai motif dan warna yang cantik dan menarik sebagai pembungkus rangkaian tersebut. Ditambah lagi dengan pemakaian pita serta aksesoris lain.

6) Dominance dan Accent (Focal Point). Prinsip ini dapat diwujudkan dengan pemilihan bahan yang memiliki ukuran dan bentuk unik serta warna yang mencolok. Dari hasil rangkaian peserta terlihat bahwa pemilihan warna yang digunakan hampir sama karena keterbatasan bahan yang dimiliki. Namun pada rangkaian tradisional, titik berat atau aksen rangkaian dapat diwakili oleh kreasi lipatan dan torehan janur yang unik.

Di sisi lain, terdapat beberapa kendala yang ditemui selama pelaksanaan kegiatan pelatihan ini. Pertama, peserta pelatihan belum memberi perhatian penuh pada penerapan protokol kesehatan, seperti mencuci tangan dengan sabun atau menggunakan hand sanitizer, memakai masker, dan menjaga jarak aman dengan orang lain. Panitia telah menyediakan tempat mencuci tangan dan sabun, mengatur kursi antar peserta dengan jarak tertentu, menyediakan makanan dalam kondisi tertutup/terbungkus. Panitia sudah beberapa kali mengingatkan peserta untuk memperhatikan protokol kesehatan tersebut, namun masih seringkali diabaikan. Kesadaran masyarakat mengenai hal ini perlu ditingkatkan, untuk mempersiapkan diri menuju kondisi new normal. Kendala lainnya adalah variasi karakteristik peserta yang cukup berbeda. Peserta pelatihan berasal dari berbagai latar belakang yang berbeda, mulai dari siswa SMA/SMK, pekerja pariwisata, ibu rumah tangga, dan guru. Selain itu, penguasaan kemampuan dasar, terutama dalam pembuatan kreasi janur, juga cukup jauh. Perbedaan yang cukup signifikan ini merupakan tantangan untuk fasilitator menyampaikan materinya karena daya tangkap peserta yang bervariasi.

Pada akhir kegiatan, para peserta diminta untuk memberikan evaluasi terhadap keseluruhan kegiatan pelatihan yang terbagi menjadi beberapa indikator. Hasil penilaian peserta disajikan pada Tabel 1.

Tabel 1: Penilaian Peserta terhadap Kegiatan Pelatihan [Sumber: Hasil Kuisioner ]

\begin{tabular}{|c|c|c|c|c|c|c|}
\hline \multirow[b]{2}{*}{$\begin{array}{l}\mathbf{N} \\
\mathbf{0}\end{array}$} & \multirow[b]{2}{*}{ Indikator } & \multicolumn{5}{|c|}{ Jawaban } \\
\hline & & $\begin{array}{l}\text { Sangat } \\
\text { Tidak } \\
\text { Puas }\end{array}$ & $\begin{array}{l}\text { Tidak } \\
\text { Puas }\end{array}$ & $\begin{array}{l}\text { Cukup } \\
\text { Puas }\end{array}$ & Puas & Sangat Puas \\
\hline 1 & $\begin{array}{ll}\text { Kepuasan } & \text { peserta } \\
\text { mengikuti } & \text { seluruh } \\
\text { rangkaian kegiatan. } & \end{array}$ & & & & 3 & 27 \\
\hline 2 & $\begin{array}{l}\text { Penyambutan/penerimaan } \\
\text { panitia saat awal kegiatan }\end{array}$ & & & 3 & 10 & 17 \\
\hline 3 & $\begin{array}{l}\text { Penerapan protokol } \\
\text { kesehatan dalam pelatihan }\end{array}$ & & & & & 30 \\
\hline 4 & Manfaat materi bagi peserta & & & & & 30 \\
\hline 5 & $\begin{array}{l}\text { Teknik penyampaian materi } \\
\text { dari fasilitator/narasumber }\end{array}$ & & & & 5 & 25 \\
\hline
\end{tabular}




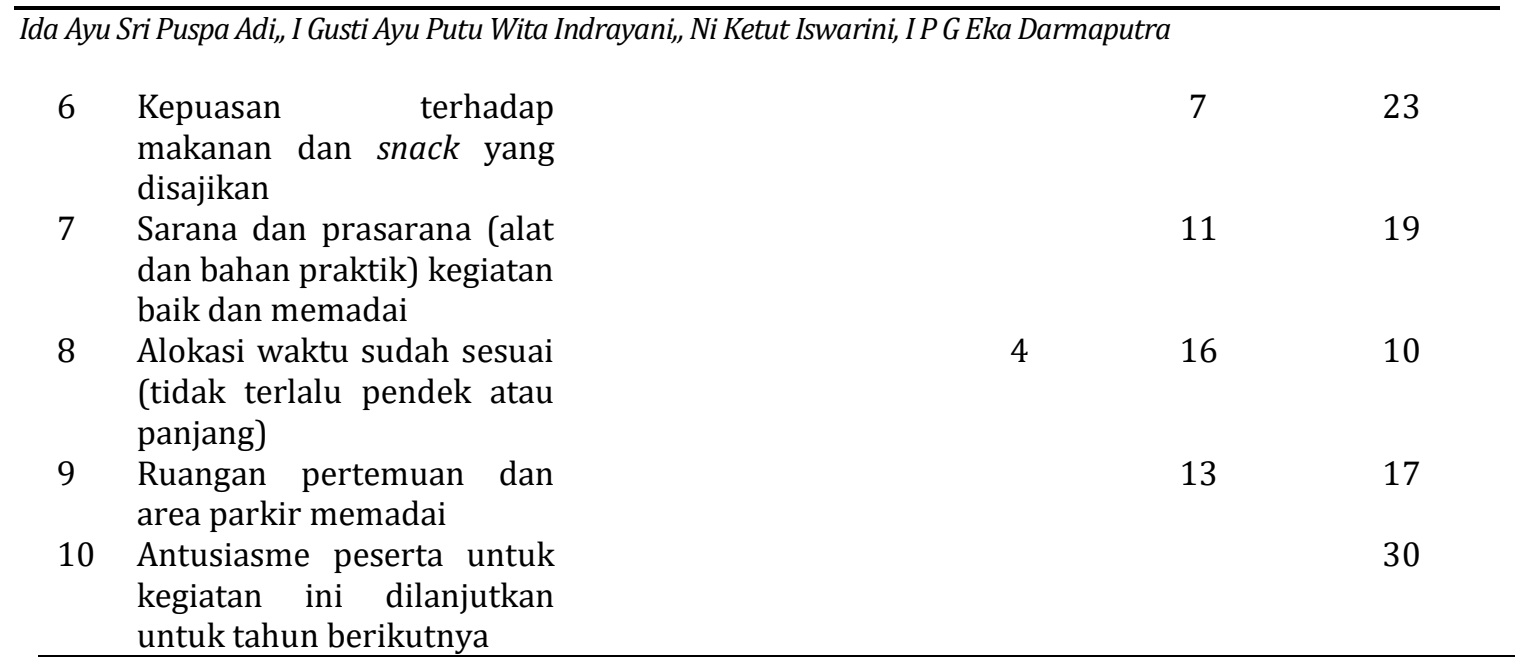

\section{Jumlah}

Dari hasil evaluasi peserta pada Tabel 1 dapat dilihat bahwa secara keseluruhan peserta merasa sangat puas terhadap pelaksanaan kegiatan pelatihan ini. Beberapa indikator yang mendapatkan nilai sangat tinggi adalah penerapan protokol kesehatan, materi pelatihan, dan fasilitator/narasumber. Hal ini membuat peserta merasa sangat antusias untuk mengikuti kegiatan pelatihan serupa yang akan dilaksanakan tahun berikutnya.

\subsection{Dampak dan Keberlanjutan Kegiatan}

Salah satu tujuan dari pelatihan ini adalah memberikan wawasan kewirausahaan dari perspektif seni merangkai bunga, dimana dapat memanfaatkan hasil kebun serta bahan-bahan yang mudah ditemui di sekitar tempat tinggal. Tidak hanya dikombinasikan dengan bunga, tetapi juga dapat dikombinasikan dengan buah dan benda lainnya. Perspektif kewirausahaan yang ingin ditekankan pada pelatihan ini adalah membuat seni floral yang dapat dikomersialisasikan tidak harus bermodal besar. Dengan bahan yang ada di sekitar dan dikemas dengan kreatif juga bisa dikembangkan untuk mendatangkan penghasilan tambahan. Didukung dengan potensi alam di Desa Wisata Gunung Salak yang sangat banyak, bisnis merangkai bunga sangat berpotensi untuk dijadikan salah satu usaha kewirausahaan masyarakat. Hal ini dikuatkan dengan tren selebrasi yang mulai berkembang di masyarakat saat ini, dimana hampir setiap kegiatan mulai dari yang berskala kecil hingga besar membutuhkan dekorasi rangkaian bunga sebagai unsur penunjang interior dan pembentuk suasana.

Untuk memastikan keberhasilan program pelatihan seni merangkai bunga sebagai unsur dekorasi, maka kegiatan serupa dalam bentuk pendampingan atau pembinaan perlu dilakukan selanjutnya. Hal ini tentunya akan dapat terselenggara dengan baik melalui kordinasi dan kerjasama tahapan berikutnya dengan pengurus Desa Wisata Gunung Salak. Selain itu, kerjasama juga dapat dilakukan dengan melibatkan Ikatan Perangkai Bunga Indonesia (IPBI) yang merupakan ikatan asosiasi profesi di bidang seni floral. Melalui kerjasama dengan berbagai pihak, maka dapat dibentuk desa wisata binaan yang berfokus pada bisnis merangkai bunga dan dekorasi yang banyak dibutuhkan saat ini. 


\section{KESIMPULAN}

Kegiatan pelatihan ini memberi wawasan dan pengetahuan bagi masyarakat di Desa Wisata Gunung Salak untuk memanfaatkan potensi alam di desanya dan memberdayakan keterampilan local genius yang dimiliki masyarakat Bali dalam mengolah janur. Wawasan, pengetahuan dasar, dan keterampilan merangkai bunga sederhana yang diajarkan oleh para fasilitator hendaknya dapat diasah secara mandiri oleh para peserta pelatihan. Keterampilan ini kemudian dapat ditingkatkan menjadi usaha kewirausahaan bagi masyarakat desa karena memiliki prospek bisnis yang baik saat ini. Untuk selanjutnya, diharapkan program dapat dilanjutkan dengan bekerjasama dengan asosiasi profesi yang relevan seperti Ikatan Perangkai Bungan Indonesia (IPBI) untuk mewujudkan desa binaan di bidang seni merangkau bunga dan dekorasi.

\section{PERNYATAAN PENGHARGAAN}

Penulis mengucapkan terimakasih yang sebesar-besarnya kepada Pusat Penelitian dan Pengabdian kepada Masyarakat Politeknik Pariwisata Bali yang telah mengkordinir kegiatan dan mengalokasikan anggaran dalam pelaksanaan kegiatan pelatihan ini.

\section{DAFTAR PUSTAKA}

Clark, A., Holland, C., Katz, J., and Peace, S. (2009). Learning to see: lessons from a participatory observation research project in public spaces. International Journal of Social Research Methodology, 12(4), 345-30.

Kesby, M. (2000). Participatory diagramming: deploying qualitative methods through an action research epistemology. Area, 32, 423-435.

Pain, R., \& Francis, P. (2003). Reflections on participatory research. Area, 35, 46- 54. Suprastayasa IGNA., Adi IASP. \& Iswarini K. 2020. Pelatihan Merangkai Bunga Bagi Masyarakat Desa Wisata Gunung Salak, Tabanan, Bali Jurnal Pemberdayaan $\begin{array}{llll}\text { Pariwisata, } & \text { Volume } & 2 & \text { (2), }\end{array}$ http://jurnalpariwisata.stptrisakti.ac.id/index.php/JPP/article/view/1430

Dewi, M.H. U., Fandeli, C., \& Baiquni, M., 2013. Pengembangan Desa Wisata Berbasis Partisipasi Masyarakat Lokal Di Desa Wisata Jatiluwih Tabanan, Bali, Kawistara 129 Volume 3 No. 2, 17 Agustus 2013 Halaman 117-226 